\title{
Experimental study on behavior of precast shear wall using post-cast at the connection
}

\author{
ZHI Qing 1, a , SONG Jingran ", b, GUO Zhengxing 1, c \\ ${ }^{1}$ School of Civil Engineering, Southeast University, Nanjing, China \\ a zhiqingjr@163.com, b 15105182597@163.com, coguozx1956@126.com
}

\begin{abstract}
Keywords: precast shear walls, post-cast, connection
Abstract. The seismic behavior of precast concrete structure wall mainly depends on connection of the shear walls, and constrains at edge elements. The strength of concrete in embedded column area is also especially important. This paper explores a mothod of connection for prefabrication that was post-cast at the connection when the precast wall was assembling. To investigate the failure mechanism of this kind of precast shear walls, a precast concrete wall specimen is studied and tested in this paper. Test results indicate that this kind of connection may effectively improve the behavier of precast shear walls, and ensure that the seismic performance of the precast walls can be equated with cast-in-place specimen.
\end{abstract}

\section{Introduction}

The seismic behavior of precast concrete structure is not better than the cast-in-place structure under the same conditions due to their particular characteristic of precast concrete structure. Since the Tangshan Earthquake of China in 1976, the application of precast concrete structure became more and more conservative in China. And this conservativeness in engineering may become higher in other earthquake prone countries. In addition, it was suspect to design and construct with precast connections duo to their poor seismic behavior. Nowadays, the disadvantages of traditional cast-in-place construction become increasingly apparent. For example, it requires much more resource and labors to construct, and the environmental pollution is also a severe problem by the cast-in-place construction.

Nowadays, the application of precast shear walls was increasingly used in seismic areas (e.g. [1-5]). However, the seismic performance of precast shear walls such as ductility is poorer than cast-in-place wall. This is mainly based on the following aspects. (1) The common destruction of precast shear wall specimen is manifested in early crushing of edge elements concrete. The seismic behavior such as the ductility, rigidity, and bearing capacity of shear walls are influenced by the edge elements. So strengthening the boundary region is believed to have significant influence to improve the seismic behavior. (2) There is construction joint at the precast shear wall connection which will become weak section along the wall height. Because the bonding behavior of precast structure at the connection is not better than the common cast-in-place structure, and the hysteretic pinch effect is also greater under the action of reinforcement stress-slip and strain penetration, the seismic energy dissipation properties of precast structure are inferior to cast-in-place structure. (3) The deformation at the connection will be large and complicated due to end rotation at the interface between the base and the wall panel, and the plasticity spread along the precast shear wall. Hence, the bear capacity of this section declines and all following deformations concentrate in the gap opening at the weak section, and the strain demand on the boundary reinforcements increases disproportionately [6].

Therefore, the seismic behavior of precast walls depends mainly on the connection between base and upper components and constrains at edge members. And the concrete strength in the embedded column area is especially important.

In a word, in order to improve the seismic behavior of the precast concrete shear walls and make the precast shear wall structure have equivalent or closed seismic performance to cast-in-place structure, this paper presented a new method of prefabrication that is the manner of post-cast to provide stable connection that transfer stress well. 


\section{Experimental scheme}

This kind of precast concrete shear walls were tested under low reversed cyclic loading. This test is a joint test. There are a total of 2 shear wall specimens. Specimens CW is cast-in-place as comparison specimen. The other is precast concrete shear wall PW. Two specimens have the same dimentions that are $3400 \mathrm{~mm}$ tall, $1700 \mathrm{~mm}$ wide and $200 \mathrm{~mm}$ thick. Fig. 1 shows the details of the reinforcement layout of the precast shear wall. Specimen $\mathrm{CW}$ is a common cast-in-place concrete shear wall and its renforcement ratio is the same with specimen PW. Therefore, its reinforcement layout is not given in the figure.
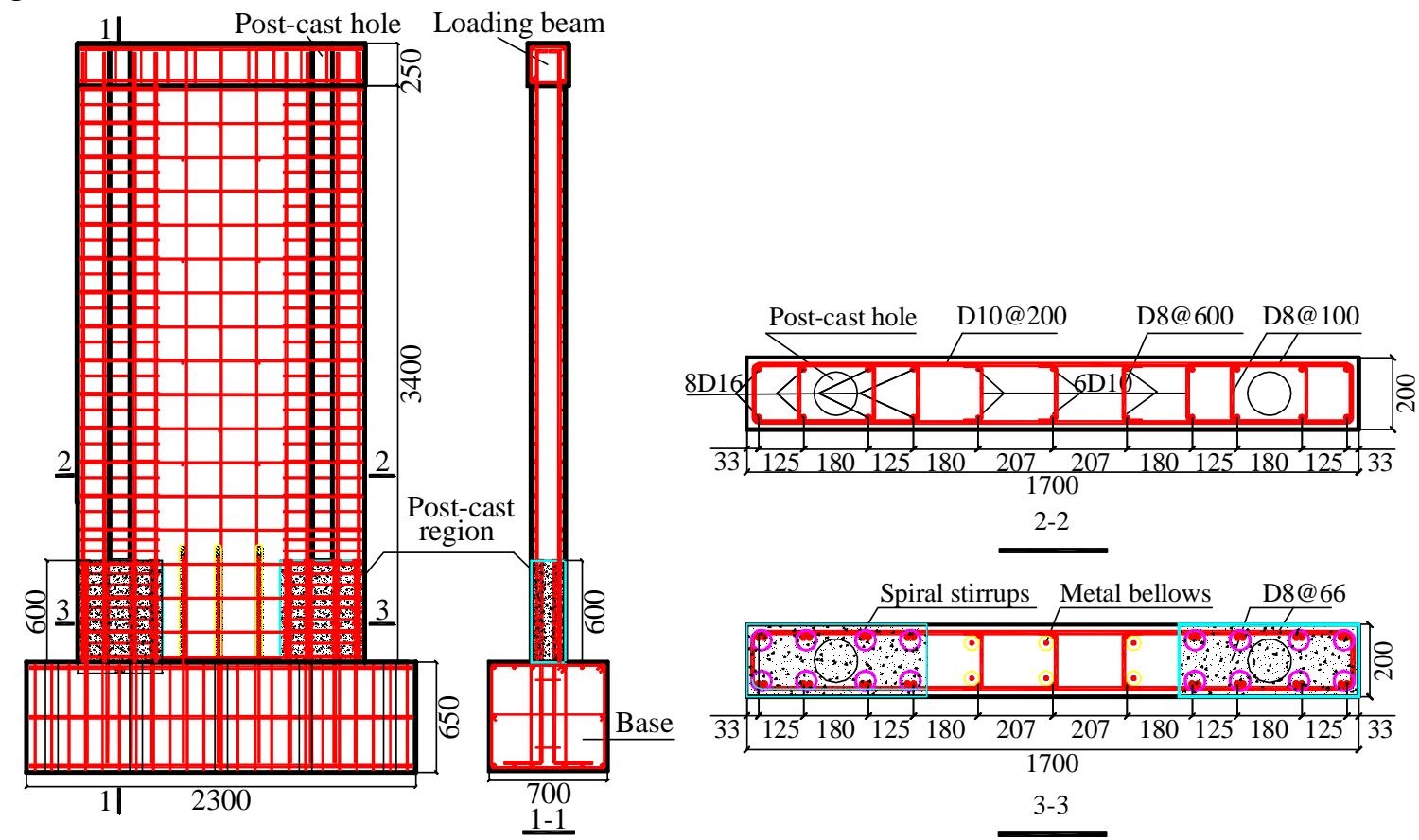

Fig. 1 Reinforcement layout of precast test unit . All dimensions in [mm].

The longitudinal reinforced bars and stirrups are HRB400 and HRB235 [7, 8], respectively. Concrete grade is C35 [7, 8]. Concrete and steel bar grade of precast specimens are consistent with those of cast-in-place specimens. The thickness of concrete cover of the two specimens is $20 \mathrm{~mm}$. Cast-in-place specimen structure meet specification requirements. The reinforcement ratio of precast specimen is the same with that of cast-in-place specimen for the principle. These material specimens were selected from the shear walls and were then cast at the same time.

\section{Experiment discussion}

Failure mechanisms. In this experiment, attentions were focused on the lateral resistance capacity, the failure modes and horizontal force-top displacement hysteretic curves. The whole force process can be divided into the following three stages: (1) no cracking stage (namely linear elastic stage); (2) stage from cracking to yielding; (3) post yield stage. The final damage of the shear wall specimens is demonstrated in Figure 2.

Like other shear wall tests, the two specimens were failed with crack development and concrete crush. But the damages of the two specimens were bending controlled. From the test results of cast-in-place specimen CW and precast specimens PW, we can find that the overall performance of precast specimen PW was slightly poorer than cast-in-place specimen $\mathrm{CW}$. The most obvious aspect was that crack force was lower. This kind of problem is difficult to be solved for the precast concrete shear walls which do not apply prestressing force. But the difference of overall behavior was not obvious. 


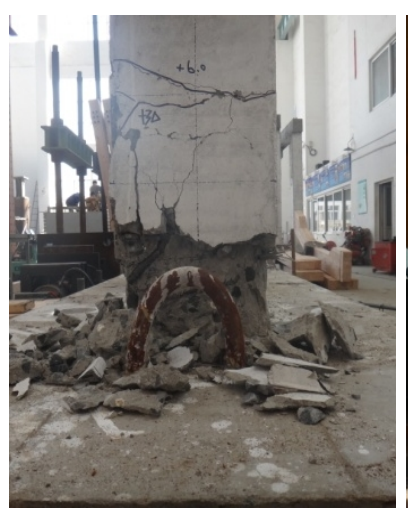

(a) $\mathrm{CW}$

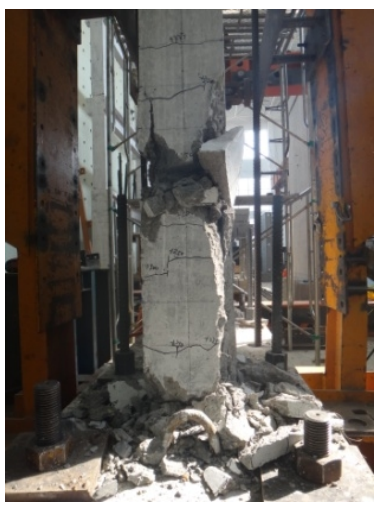

(b) PW

Fig. 2 Typical falures of shear wall specimens

Horizontal force-top displacement hysteretic curves. The lateral force-top horizontal displacement hoops curves during the test are given in Fig. 3. Table 1 lists the cracking force $f_{c r}$, yield force $f_{y}$, peak force $f_{u}$, ultimate deformation $\Delta_{u}$, deformation ductility $\mu$ during the test. The specimens were tested by two method of loading that were load control before specimens yield and displacement control after specimens yield. On the whole, at the load control stage, longitudinal reinforcements of the two specimens were elastic. Load-displacement relationships obtained from the test results were almost linear and residual deformations were small. There was no obvious degradation for stiffness of the specimens at this stage. After yield, the hysteresis curves began to tilt to the displacement axis and the force-displacement hoops were plump and s-shaped. Compared to the cast-in-place specimen CW, it can be found that hysteretic behavior of precast specimen PW equaled to cast-in-place specimen CW. The force-top displacement hoops of specimen PW were almost as plump as specimen CW. Lateral stiffness before the outer reinforcement yield and lateral stiffness degradation after outer reinforcement yield of the precast specimens were all almost the same as the cast-in-place specimen. Deformation ductility $\mu$ of CW and PW were 6 and 5 respectively which difference was not obvious and all met Eurocode 8 [9] DCM minimum ductility. That mean the method of post-cast at the connection could ensure that the behavior of this kind of precast concrete shear wall was almost equivalent to cast-in-place shear wall.

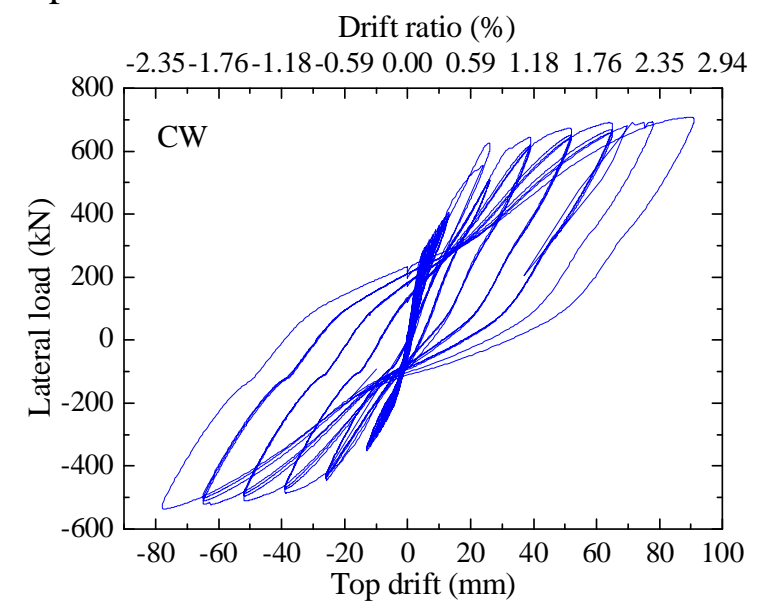

(a) specimen $\mathrm{CW}$

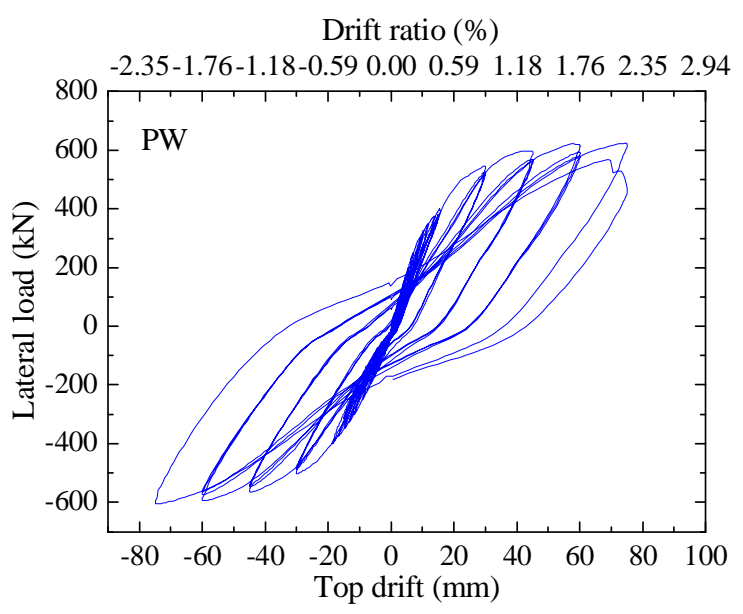

(B) specimen PW

Fig. 3 Hysteretic loop curve of the lateral force and the top horizontal displacement Table 1 Test result of the specimens

\begin{tabular}{llllll}
\hline $\begin{array}{l}\text { Specimen } \\
\text { number }\end{array}$ & $\begin{array}{l}\text { Cracking } \\
\text { force } f_{c r}[\mathrm{kN}]\end{array}$ & $\begin{array}{l}\text { Yield force } \\
f_{y}[\mathrm{kN}]\end{array}$ & $\begin{array}{l}\text { Peak force } f_{u} \\
{[\mathrm{kN}]}\end{array}$ & $\begin{array}{l}\text { Ultimate } \\
\text { deformation } \Delta_{u} \\
{[\mathrm{~mm}]}\end{array}$ & $\begin{array}{l}\text { Deformation } \\
\text { ductility } \mu\end{array}$ \\
\hline $\mathrm{CW}$ & 175 & 380 & 690 & 78 & 6 \\
$\mathrm{PW}$ & 130 & 400 & 625 & 75 & 5 \\
\hline
\end{tabular}




\section{Conclusions}

From above, as current understanding, the connection has great influence in the behavior of precast concrete shear wall. In this paper, a precast concrete shear wall specimen with a cast-in-place specimen was tested under low reversed cyclic load. The failure modes and force-top displacement hysteretic behavior were studied. Test results show that this kind of precast concrete shear wall which prefabricated using post-cast demonstrated well hysteretic behavior compared with the cast-in-place specimen, and deformation ductility exceeded Eurocode 8 DCM minimum ductility. But the crack force of precast specimen was lower than cast-in-place specimen. In a word, the seismic behavior of the precast concrete PW has equivalent or closed seismic performance to cast-in-place structure CW.

\section{Acknowledgements}

The authors gratefully acknowledge financial support from the Research Innovation Program for College Graduates of Jiangsu Province (Grant No. KYLX15_0079) and from the National "Twelfth Five-Year" Plan for Science \& Technology (No.2011BAJ10B03).

\section{References}

[1] Guo, T., Zhang, G. D., and Chen, C. Experimental Study on Self-Centering Concrete Wall with Distributed Friction Devices. Journal of Earthquake Engineering 18(2) (2014) 214-230.

[2] Pavese, A., Bournas, D. A. "Experimental assessment of the seismic performance of a prefabricated concrete structural wall system. Engineering Structures 33(6), (2011) 2049-2062.

[3] Zhang, H. M., Lu, X. L., Duan, Y. F. and Li. J. B. Experimental Study and Numerical Simulation of Partially Prefabricated Laminated Composite RC Walls. Advances in Structural Engineering 14(5) (2011), 967-979.

[4] Quiroz, L. G., Maruyama, Y., and Zavala, C. Cyclic behavior of thin RC Peruvian shear walls: Full-scale experimental investigation and numerical simulation. Engineering Structures 52 (2013) 153-167.

[5] Smith, B. J., Kurama, Y. C., and McGinnis, M. J. Behavior of Precast Concrete Shear Walls for Seismic Regions: Comparison of Hybrid and Emulative Specimens. Journal of Structural Engineering 139(11) (2013), 1917-1927.

[6] Dazio, A, Beyer, K; and Bachmann, H. Quasi-static cyclic tests and plastic hinge analysis of RC structural walls. Engineering Structures 31(2009), 1556-1571.

[7] GB50010-2002. Code for Design of Concrete Structures. Chinese code, Beijing, China (in Chinese) (2002).

[8] GB 50010-2010. Code for design of concrete structures. Chinese code, Beijing, China (in Chinese) (2002).

[9] CEN EN 1998-1-1: Eurocode 8 - Design of Structures for Earthquake Resistance. Part 1: General Rules, Seismic Actions and Rules for Buildings, Comite Europeen de Normalisation (2005) CEN/TC 250. 